SLOVO, sv. 71 (2021), 105-119, Zagreb 2020.

Petra STANKOVSKA

UDK 272-282.7:003.349.1

Filozofska fakulteta Univerze v Ljubljani

811.163.42'373.2

Ljubljana, Slovenija

petra.stankovska@ff.uni-lj.si

Izvorni znanstveni članak

Primljen: 18. svibnja 2020.

Prihvaćen: 20. listopada 2020.

\title{
VLASTNÍ JMÉNA V PARIMEJNÍM TEXTU KNIHY EXODUS V CHORVATSKOHLAHOLSKÝCH BREVIÁŘÍCH A MISÁLECH
}

V př́spěvku se zaměříme na zkoumání vlastních jmen vyskytujících se v textu knihy Exodus, který je obsažen v chorvatskohlaholských breviárích a misálech 13. - 15. stol., a zároveň i ve staroslověnském parimejníku. Konkrétně se tedy budeme věnovat téměř celé 1., 2., 14. a 15. kapitole a částem z 3., 12., 13. a 24. kapitoly. Propria shromáždíme a rozdělíme do skupin podle toho, jakým způsobem byla přejata do církevněslovanského textu, jakou mají hláskoslovnou podobu a jak je možné tuto podobu vysvětlit. Zaměříme se i na reflexi rozdílů přejímek podle řecké předlohy, resp. $v$ podobě známé ze staroslověnského parimejníku a přejímek z latinské předlohy.

Klíčová slova: Exodus, staroslověnština, chorvatská církevní slovanština, překlad, propria

\section{PŘEKLAD VLASTNÍCH JMEN DO CÍRKEVNÍ SLOVANŠTINY}

Překlad, resp. přepis či přejímání vlastních jmen z jinojazyčného textu není vždy jednoduchý a na jejich výslednou podobu v přeloženém textu může mít vliv velké množství faktorů jako: forma ve výchozím jazyce, odlišný fonologický systém cílového jazyka, zvyklosti při přejímání určitých fonologických vlastností výchozího jazyka do jazyka cílového, zprostředkování přes jiné jazykové okolí a třeba i místní jazykové zvyklosti, adstrátní vlivy jiných jazyků, tradice, textová tradice apod. ${ }^{1}$ Proto také dochází i ve staroslověn-

1 U vlastních jmen pozorujeme velmi často různé typy adaptace zejména na úrovni hláskoslovné, které podrobněji popisuje např. FILIPOVIĆ 1986: 58-59, 69-76. 
ských a v církevněslovanských textech $\mathrm{k}$ tomu, že $\mathrm{v}$ jedné tradici či textu určitého žánru se setkáváme $\mathrm{s}$ jednou variantou jména, $\mathrm{v}$ jiné $\mathrm{s}$ druhou.

V překladech biblických textů do staroslověnštiny, resp. církevní slovanštiny je to známá situace a výjimkou není i několik hláskoslovných podob stejného jména. Často se pak rozdíly ve výsledné slovanské podobě jména užívají k posuzování toho, zda byla bezprostřední předloha překladu řecká (Vitleem) nebo latinská (Betleem). ${ }^{2}$ Tímto však většinou zkoumání podoby vlastních jmen ve staroslověnských a církevněslovanských textech končí a můžeme najít pouze doklady o jejich podobě at' už v edicích památek, $\mathrm{v}$ indexech k nim anebo ve slovnících.

Zvláštní a poměrně složitá situace - již jen ohledně textové tradice biblického textu -je v chorvatské redakci církevní slovanštiny. Biblický text se totiž $\mathrm{v}$ této tradici dochoval $\mathrm{v}$ několika podobách a proveniencích: (1) texty převzaté ve starším staroslověnském překladu vypracovaném z řečtiny a minimálně upravené (většina evangelního a žaltářního textu, některé části starozákonních knih - zejména $\mathrm{v}$ tradici liturgických knih, breviáře a misálu, zřejmě starší, snad z pol. 13. stol. a ze severu chorvatského pobřeží - Senj, ostrov Krk, Istrie), (2) převzaté ve straším staroslověnském překladu, ale výrazně redigované podle latinské předlohy (zejména starozákonní texty $\mathrm{v}$ »mladších « redigovaných liturgických knihách - snad z pol. 14. stol., jejichž provenience se obecně spojuje s jižní částí chorvatského pobřeží - Zadar, Krbava), (3) biblické texty přeložené jistě $\mathrm{z}$ latinské předlohy přímo $\mathrm{v}$ Chorvatsku pro chorvatskohlaholský breviář a misál (at' už v »severní«, starší tradici, nebo v »jižní« mladší - části některých biblických knih, např. Genesis, Exodus, Jeremiáš, Job aj., nebo zřejmě veškerý text knih Makabejských, Ester, Judit aj.).

Vzhledem ke složitosti a šíri problematiky, jakož i k omezenému prostoru $\mathrm{v}$ tomto př́spěvku se budeme věnovat pouze analýze textu $\mathrm{z}$ knihy Exodus, a protože předpokládáme, že nejzajímavější závěry mohou vyplynout ze srovnání podoby vlastních jmen ve staroslověnských památkách a v chorvatskohlaholské tradici, budeme dále vycházet především z textu, který je obsažen i v parimejníku a neparimejní části budeme studovat spíše doplňkově. Většina proprií z knihy Exodus je dochována v breviáři, ale protože se velké množství jmen opakuje i v úryvcích z misálu, přibíráme pro úplnost i perikopy misální. S ohledem na všechna omezení tato práce nemá, a ani nemůže mít ambice zpracovat danou problematiku v celé její šíři, může však poukázat na zajímavost, aktuálnost a užitečnost srovnání tohoto druhu.

2 O způsobech adaptace řecké bety a jiných souhlásek viz např. DIELS 1932: 146-147. 


\section{TEXT KNIHY EXODUS V CHORVATSKOHLAHOLSKÝCH PAMÁTKÁCH}

Čtení z knihy Exodus jsou v chorvatskohlaholských breviáŕích - podobně jako jiná biblická, patristická či hagiografická čtení - doložena v různě dlouhých úryvcích a textologicky jsou poměrně pestrá zejména ve smyslu vztahu k parimejnímu překladu a případným pozdejš̌ím úpravám. Ve většině dochovaných chorvatskohlaholských breviár̆ů se kapitoly z knihy Exodus čtou o 4. neděli postní, a to v rozsahu 3.-4. kapitoly, Breviár Víta z Omišlje až do 15. kapitoly s četnými převyprávěnými a zkrácenými pasážemi ${ }^{3}$. Pouze Breviár Vita z Omišlje (a částečně Vrbnický třetí breviár a tzv. Tkonský fragment ${ }^{4}$ ) obsahují 1. a 2. kapitolu. Jako kantikum v žaltářích jsou uvedeny verše z 15. kapitoly (Ex 15,1-19) a v misálech se čtou úryvky: Ex 12,1-11; 14,24-31; 15,$1 ; 15,13 ; 15,27-16,4 ; 16,6-7 ; 20,12-24 ; 24,12-18 ; 32,7-14 ; 37,1-14$ (BAKMAZ 2010: 76).

Do chorvatskohlaholského breviářního čtení byl převzat překlad parimejní na všech místech, kde existoval (Ex 1,1-20; 2,5-22 a Ex 18,4; Ex 13,20-22; Ex 14,1-31 a Ex 15,1), přičemž na začátku čtení na 4. postní neděli, které se vyskytuje ve všech breviárích (Ex 3,1-8), je tento parimejní text výrazněji přizpůsobený latinské verzi. Neparimejní části textu byly zřejmě na chorvatském území a př́mo pro breviář přeloženy z latinské předlohy, nejspíš breviáŕní (STANKOVSKA 2019: 392). Stejná situace u parimejních a neparimejních částí textu je i v misálních lekcích (STANKOVSKA 2018: 167).

Vzhledem k tomu, že se budeme snažit srovnat podobu přejatých vlastních jmen v staroslověnské tradici rukopisů podle východního ritu a chorvatskohlaholských knih západního obřadu, zaměříme se dále na úseky textu, které nacházíme paralelně v parimejnících a chorvatskohlaholském breviáři (včetně žaltáře): Ex 1,1-20; 2,5-22; 18,4; 3,1-8; 13,20-22; 14,1-31; 15,1; 15,1-19; 15,22-27 a misále: Ex 12,1-11; 14,24-29; 15,27-16,1;24,12-18.

\footnotetext{
3 Breviár̆ Vita z Omišlje má ze všeh dochovaných chorvatskohlaholských breviářu nejrozsáhlejší text knihy Exodus, přesněji verše: Ex 3,1-22; 4,1-14; 4,27-29; Ex 5,1-4; 5,6-7; Ex 12,46-47; 11,3-5; 11,7-8; 7,7-12; Ex 11,5; Ex 12,42; 12,40; 12,41; Ex 13,17-18; 13,2022; 14,1-5; 14,6-14; Ex 14,1-zač. 14,15; část 14,2; Ex 23,20-25; 14,15-15,21; Ex 15,2-4 (STANKOVSKA 2019: 373-376).

4 Milan Mihaljević upozornil na to, že část textu této kapitoly je dochována i na Tkonském fragmentu na Mezinárodní vědecké konferenci »Fenomen glagoljice« v Zadaru a Biogradu na Moru, konané 12. - 13. 5. 2017. (MIHALJEVIĆ 2017).
} 


\subsection{Vlastní jména z textu Exodu v chorvatskohlaholských knihách a jejich rozdělení}

V takto vymezených úsecích textu bylo celkem vyexcerpováno 163 výskytů propriií (většinou antroponym, toponym, oikonym, hydronym aj.), z nichž některá se mnohokrát opakovala (egjuptb a odvozeniny, eguptjaninb, evrěi a odvozeniny, moisěi, izrail a odvozeniny). Navíc jsou to pojmenování, jejichž forma je poměrně ustálená a stejná jak v nejstarších staroslověnských památkách, tak i v chorvatskohlaholské tradici. Ostatní jména byla přejímána do chorvatskohlaholských knih nejrůznějším způsobem, takže celkově můžeme propria, která se vyskytují v parimejní i chorvatskohlaholské tradici textu Exodu rozdělit po srovnání do tř́ skupin: (1) ta, která jsou v obou tradicích stejná; (2) v chorvatskohlaholské tradici jsou hláskoslovně jiná než v parimejnímu textu; (3) v chorvatskohlaholské tradici jsou některá dodaná nebo silně zkomolená jména a některá zřejmě ovlivněná latinskou formou.

\subsubsection{Propria ve stejné podobě v chorvatskohlaholské tradici a v parimejniku}

Do této skupiny řadíme propria, která jsou alespoň $\mathrm{v}$ jednom chorvatskohlaholském a alespoň v jednom rukopise parimejníku doložená ve stejné podobě. Takto eliminujeme př́ípady, kdy některý z rukopisů, což se stává v opisech všech zkoumaných druhů knih, má jméno opsané chybně, nejrůzněji zkomolené či interpolované.

Většina proprií v této skupině jsou jména často se vyskytující v Bibli obecně, a proto jsou i ve staroslověnštině formálně poměrně jednotná a $v$ chorvatskohlaholské tradici je to stejné. O tom, že byla jména převzata do chorvatskohlaholské tradice ze staroslověnských zdrojů (parimejník, ale i evangeliáŕ, žaltář a jiné knihy) svědčí hláskoslovná podoba, kterou nelze spojit s latinskou ${ }^{5}$ :

5 Jednotlivá jména jsou ve skupinách řazena podle prvního verše, v němž se vyskytují a v pádu, který je na daném místě doložen. Za chorvatskohlaholskou podobou je zkratka Br (citováno z breviáře), Cant (citováno podle kantika), Mis (citováno z misálu). Citace z breviáře jsou podle vlastní excerpce, Cant podle edice M. Šimić (ŠIMIĆ 2014) a Misálu podle edice (ŠTEFANIĆ 1973), částečně podle vlastní excerpce. Pokud se jméno vyskytuje v některé z památek víckrát ve stejné podobě, nijak tuto skutečnost nezaznamenáváme a citujeme pouze první místo výskytu počítáno od začátku biblické knihy. Staroslověnská podoba z parimejníku je bez dalšího označení citována podle edice Grigorovičova parimejníku (RIBAROVA; HAUPTOVA 1998), pokud jsou v edici varianty, označují se zkratky rukopisů edice (Grig, 
Ex 1,3: венziamиz Grig, вениаминь L, Z - veniêmin' (Br) Beviauıv, Beniamin - tradičně se v těchto pozicích užití slovanského »V« vysvětluje logicky přejímkou z řečtiny, $v$ níž se $\beta$ četla jako hláska $» V$ « a byla tedy odpovídajícím grafémem přepsána do slovanského textu. Breviářní Veniamin' dobře odpovídá podobě doložené Lobkovském a Zacharijově parimejníku.

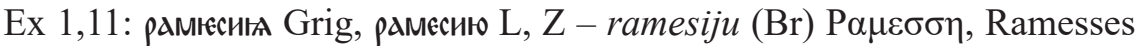
- vzhledem k jasné reflexi koncovky řecké podoby, která se liší od latinské, je třeba považovat i podobu $\mathrm{v}$ chorvatskohlaholském textu za přejímku z řecké verze.

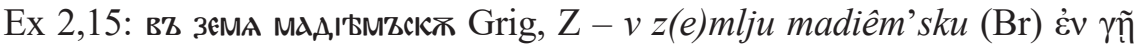
M $\alpha \delta 1 \alpha \mu$, in terra Madian - tady je rozdíl nepatrný v kvalitě koncové nazály, nicméně i breviáře zachovávají bilabiálu, narozdíl od dentály $» n$ « v latinské verzi.

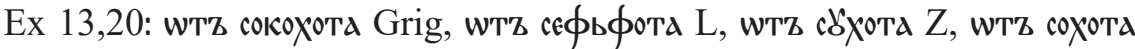
(Pich) - ot sokota $(\mathrm{Br}) \dot{\varepsilon} \kappa \Sigma$ o $\chi \omega \theta$, de Soccoth - v tomto př́padě sice v chorvatskohlaholské tradici nijak výrazně není vidět podoba s parimejní formou, a dokonce díky nepř́tomnosti frikativy a naopak př́itomnosti $» k$ «, které je doloženo jen v poněkud zkomolené podobě jména v Grig, bychom spíše mohli uvažovat o podobnosti s latinským přepisem jména. Nicméně vzhledem následujícímu jménu ve stejném verši, které zcela jistě vychází z parimejního přepisu, ho řadíme do této skupiny.

Ex 13,20: вZ анатот'ь - $v$ an totě $(\mathrm{Br}) \dot{\varepsilon} v \mathrm{O} \theta \mathrm{o}$, in Etham - vzhledem k tomu, že se podoba jména ve slovanském textu výrazně liší jak od řecké, tak i od latinské, je zcela nepochybné, že bylo v této formě do chorvatskohlaholského breviáře převzato ze staroslověnského parimejníku. Náslovné an- v podobě an 'tot' mohlo vzniknout na tomto místě tak, že překladatel chápal řecké $\dot{\varepsilon} v$ jako součást propria, původ koncového $-t \mathrm{v}$ slovanské podobě jména je však nejasný.

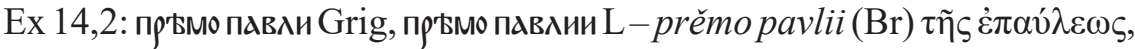
e regione Phiahiroth $-\mathrm{v}$ tomto př́padě je $\mathrm{v}$ řečtině a $\mathrm{v}$ latině textový rozdíl, zatímco $\mathrm{v}$ latině je vlastní jméno, je $\mathrm{v}$ řečtině obecné, které je přepsáno do parimejního textu a z něj pak zřejmě do breviáře, kde bylo zřejmě chápáno jako neznámé oikonymum, a snad proto nebylo ani pozměněno.

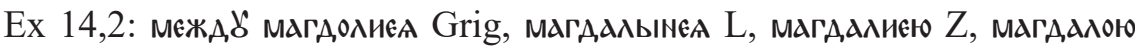

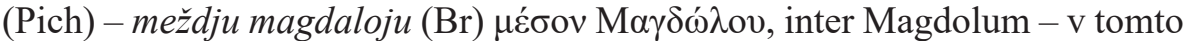

Z, L). Pokud je přibrána edice parimejních čtení z knihy Exodus (PIČCHADZE 1998), je za př́íkladem uvedeno (Pich). Žaltářní příklady jsou podle Sinajského žaltáře (SEVER'JANOV 1922) označeny (PsSin). 
př́padě je rozdíl mezi řeckou a latinskou podobou jména minimální (podobně jako v Ex 13,20), př́značná je však podoba s »a《 místo »o«, která se vyskytuje ve většině parimejních variant a v jedné, kterou uvádí Pičchadze (Pich), je dokonce tvar identický s tím, který nalézáme v chorvatskohlaholském breviáŕi.

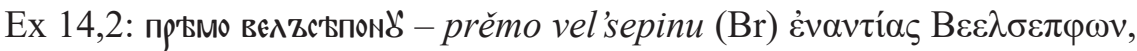
contra Beelsephon $-\mathrm{v}$ tomto př́padě je jasné přejetí náslovné souhlásky přes řečtinu, a tedy v chorvatskohlaholském breviáři je jistě podoba parimejní. Jediný rozdíl je v »i« místo »o«, což však může být i chyba písaře, který mohl snadno zaměnit např́klad špatně čitelné hlaholské »o《 za »i«.

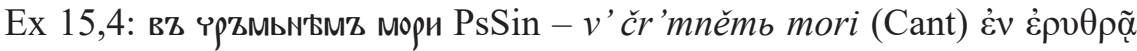
$\theta \alpha \lambda \alpha ́ \sigma \sigma \eta$, in mari Rubro - zde je opět jasná formální shoda výrazu z chorvatskohlaholského a Sinajského žaltáre.

Ex 24,13: ı( оус)z nавZгZnz - i(su)sa nav'jiina (Mis - Ill4 Ro, var. juosue Nk Hrv) 'I ní textologické skupiny (Ill4 a Ro), v nichž biblické texty nebývají výrazně revidovány podle latinské předlohy, jasná stopa převzetí formy jména z parimejního čtení (s obvyklým přepisem r pomocí ĵ). V revidovaných misálech je jméno zcela opraveno podle latinské předlohy, tedy Iosue.

Do této skupiny patř́ i jména, která mají podobu v řečtině a latině stejnou, a ani při přejímání do slovanského jazyka nelze očekávat nějaké hláskoslovné změny či charakteristické reflexe původní podoby. Na druhou stranu však jejich stejná forma $\mathrm{v}$ tradicích obou redakcí, resp. obou liturgických knih nemůže vypovídat nic o přejetí z jedné knihy do druhé. Proto zde nemá smysl uvažovat o zdroji anebo způsobu přejetí:

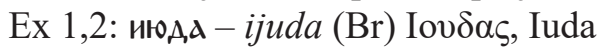

Ex 1,4: дағамz Grig, ,ань Z - danь (Br) $\Delta \alpha v$, Dan

Ex 1,4: гаA $\mathrm{Z}-\operatorname{gadb}(\mathrm{Br}) \Gamma \alpha \delta, \mathrm{Gad}$

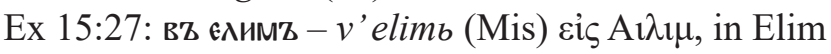

Ex 16,1: вZ поустZIна синZ - v pustinju sion 'skuju Hrv/sinskuju Ill4 Nk Ro/

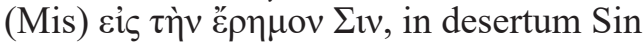

Některá jména mají v chorvatskohlaholské tradici i v parimejníku stejnou podobu, která se však nějakým způsobem liší od řecké a většinou i latinské, což svědčí o zcela jistém spojení mezi textovou tradicí obou knih:

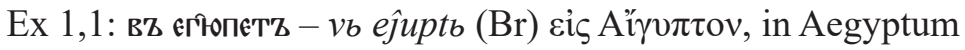

Ex 1,2: Аєвгиı - levji $(\mathrm{Br}) \Lambda \varepsilon v 1$, Levi - jediným rozdílem obou forem v tomto i předcházejícím př́kladu je přepis měkkého $r$ hlaholským děrvem (přepisujeme jako ĵ), což je ovšem běžná praxe v chorvatskohlaholských textech.

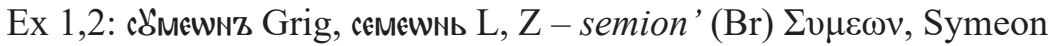




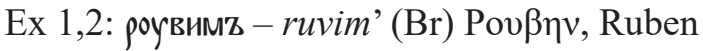

Ex 1,3: завлонь - zavolon' $(\mathrm{Br}) \mathrm{Z} \alpha \beta$ ov $\lambda \omega v$, Zabulon - v tomto i v předchozím jméně je $\mathrm{v}$ chorvatskohlaholské podobě prítomna reflexe řecké $\beta$ běžná podle aktuální výslovnosti pro staroslověnské texty jako »V《, zatímco při př́mém přejetí z latiny bychom zde očekávali »b«. Podobné je to i se samohláskou ve jménu Ruben, kde bychom při ovlivnění latinskou tradicí očekávali »e« a nikoli »i«, které opět odpovídá řecké výslovnosti.

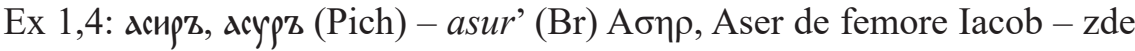
samohláska »u« v chorvatskohlaholském breviáři zcela jistě nevychází z latinského »e« a je zřejmé, že je výsledkem kopírování tradice parimejní. Zatímco Grig, Z, L mají očekávané »i« za řeckou » ๆ« podle výslovnosti, je možné, že »u« v breviáři je důsledkem opisu v parimejní tradici pomocí yžice, která mohla být zejména $\mathrm{v}$ hlaholském textu snadno interpretována jako »u« (např. DIELS 1932: 27-29). Zcela vyloučit nelze ani kontaminaci s propriem asur'

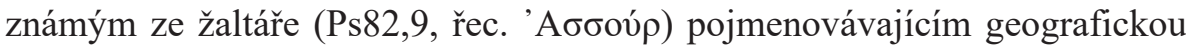
entitu.

\subsubsection{Některá jména se v chorvatskohlaholské tradici hláskoslovně liši od tradice parimejni}

Mnohdy jde o rozdíly ve skripci, které se pravidelně opakují u různých jmen (skupina a, b), anebo jako zvláštnost ojediněle (c):

a) ztráta náslovného »i« - zatímco v parimejním textu je náslovné »i« před samohláskou nebo souhláskou, v chorvatskohlaholských památkách chybí, a to pravidelně ve jménech, $v$ nichž je i v jejich latinské podobě:

Ex 1,1: 'ъ и'Łковом' - sb êkovom' (Br) I $\alpha \kappa \omega \beta$, Iacob - krom zachování staroslověnského »ě« na začátku, je zachována i reflexe »V« za řeckou $\beta$. Ve stejné formě je ve Slovníku jazyka staroslověnského doloženo pouze ve dvou chorvatskohlaholských žaltárích, Lobkovickém a Pařižském (SJS I: 847).

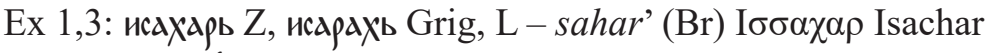

Ex 1,4: ишсифz - osip' (Br) I $\omega \sigma \eta \varphi$, Ioseph - podoba v chorvatskohlaholských textech opět nápadně odpovídá hláskové podobě staroslověnské vytvořené na základě řečtiny - za $\eta$ je i zde $» i \ll$, ačkoli v latiské podobě máme »e«. Bez náslovného »i« se ve formě ocnфz toto jméno objevuje v Zografském a Mariánském tetraevangeliu a očekávaně pravidelně v chorvatskohlaholském Lobkovickém a Pařižském žaltáři (SJS I: 783). Ve jméně je také pro chorvatskohlaholské texty typická (viz níže b) náhrada $f$ bilabiálním »p«. To 
se však vyskytuje u tohoto jména ojediněle i mimo chorvatskohlaholskou tradici, např. forma носипъ v Ps 104,17 v Dimitrijově žaltáři (podle MIKLAS 2012: 256), anebo v následujícím př́íladu, kde jsou v parimejnících na daném místě obě souhlásky $p$ i $f$.

Ex 1,11: илишполz Grig, илишфоль L, сл(z)нцеградз Z - liopols (Br) 'H $\lambda$ íov $\pi$ ó $\lambda$ s, 0 lat.

Ex 2,16: иштор' - otor' (Br), Ex 3,1: eter', var. otrona (VAT), otara (DR), ednoga (ILL) IoӨo $\rho$, Iethro - poměrně neobvykle se setkáváme s variatnou u tohoto jména. Forma otor' ve verši 2,16, a tedy i v jediném rukopise (VO) zcela jistě souvisí s parimejním iotor, pouze je podle očekávání ztraceno náslovné »i«. Stejná podoba je ve verši Ex 3,1 pouze ve Vatikánském 5. breviárí, zatímco ostatní mají eter', což by sice mohl být výsledek korekce podle latinské podoby Iethro, avšak i vzhledem ke kontextu (pasaše ovce u etera/otrona/otara/ednoga užika) se zde nabízí spíše jiné vysvětlení, že totiž opisovači prostě proprium zaměnili za zájmeno eter. Tomuto chápání odpovídá i varianta v rukopise ILL.

Ve zde shromážděném materiálu je tedy náslovné »ii ve všech vlastních jménech $v$ chorvatskohlaholských textech eliminováno, i když existuje nejen $\mathrm{v}$ řecké a staroslověnské podobě jména, ale i v latinské. Jde tedy zřejmě o zvláštní a charakteristickou tendenci chorvatské církevní slovanštiny. Jedinou výjimkou v našem materiálu je proprium ijuda (viz 2.1.1.).

b) zdá se, že dalším typickým př́znakem adaptace staroslověnské formy (konkrétně parimejní) vlastních jmen do chorvatskohlaholských textů je důsledná náhrada »f« bilabiálou »p«. Podobné stř́íání je sice okrajově známo i z nejstarších dochovaných staroslověnských památek, v našem materiálu je však pravidlem. To dokládají i následující jména:

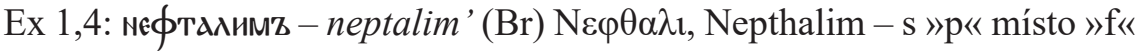
je ve Slovníku jazyka staroslověnského doloženo pouze odvozené adjektivum, a to opět $\mathrm{v}$ chorvatskohlaholských nebo jim redakčně blízkých památkách, v Nikodémově evangeliu, Lobkovickém a Pařižském žaltáři a Hvalově rukopise Apokalypsy (SJS III: 342).

Ex 1,4: ишcифz - osip' (Br) I $\omega \sigma \eta \varphi$, Ioseph (podrobněji je hlásková podoba rozebrána $\mathrm{v}$ předchozí skupině).

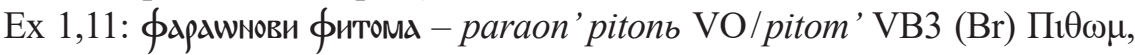
Phiton $-\mathrm{v}$ tomto př́padě uvádíme i před propriem předcházející titul, protože typ změny je stejný jako ve vlastním jménu. Opět se u názvu hodnosti stejná forma objevuje ve Staroslověnském slovniku pouze v chorvatskohlaholském Lobkovickém a Pařižském žaltáři, jednou je doloženo вapaonz v Grig (SJS IV: 739). 
Ex 1,15: сем'zпфора - sep'pora (Br) $\Sigma \varepsilon \pi \varphi \omega \rho \alpha$, Sephra

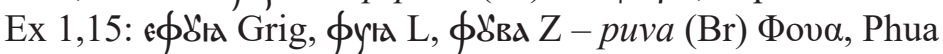

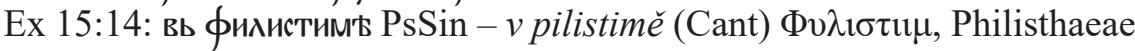
- v materiálu Staroslověnského slovníku je opět forma s »p« doložena pouze v chorvatskohlaholském Lobkovickém a Pařižském žaltáŕi (SJS IV: 747).

Zdá se, že v chorvatskohlaholské tradici je náhrada cizorodého »f « (v latině zapisovaného i jako »ph «) domácím »p « běžná zejména do poloviny 14. stol., tedy v nejstarším období doloženého chorvatskohlaholského písemnictví, i když i tehdy se řidčeji střídá s »f « (MIHALJEVIĆ 2014: 65-66). To, že se od poloviny 14. století objevuje i cizorodé $»$ « V přejatých jménech je potvrzeno mimo jiné např. z kalendáře a $\mathrm{z}$ různých míst 2. Novljanského breviáre (PANTELIĆ; NAZOR 1977) - vedle: Stipan (455a) za Stephanus, Peličišim' (459d) za Felicissimus, máme doloženo kontaminované Epefes', (60c/23) za Ephesus a zejména pak formy s »f«: Feliciě i Felikš', Fabiěn' (268r, 447d), Filicij, Bonifacij (420c), Felicitata (410a), Šim 'foriěn' (475c) aj. Jistá časová vymezenost reflexe »f« jako »p« ve výpůjčkách z jiných jazyků může být podpořena i výskytem podoby výpůjčky z řečtiny vlaspimija/blaspimija, anebo ponestra $\mathrm{z}$ lat. fenestra $\mathrm{v}$ nejstarších známých chorvatskohlaholských památkách (MIHALJEVIĆ 2014: 385, 388). Otázka reflexe »f«, resp. »ph« ve chorvatskocírkevněslovanských památkách je tedy poměrně složitá a jistě by si zasloužila podrobnější výzkum, který však výrazně přesahuje rámec tohoto př́spěvku. Vzhledem k důslednému nahrazování »f« $\mathrm{v}$ chorvatskohlaholské tradici textu Exodu bilabiálou »p« př́ jinak hláskoslovně identické podobě jmen s těmi v parimejníku bychom mohli uvažovat o dvou nebo třech přícinách tohoto stavu. Bud' o snaze eliminovat pro slovanský jazyk cizí souhlásku, nebo o vlivu písemného záznamu latinského, kde je v digrafu »ph" na prvním místě »p«. Třetí prríčinou by mohl být i adstrátní vliv italských nářečí a tedy i fonologické vlastnosti místních nářečí slovanských.

c) Zajímavá adaptace náslovného »a«, která v jiném propriu v našem materiálu zaznamenána nebyla, je u jména Mojžíšova bratra Arona, který je v chorvatskohlaholských památkách důsledně zapisován jako êrunb. Vzhledem k tomu, že u většiny jmen pozorujeme vynechání náslovné jotace (zde oddíl a), je výskyt »ja « místo ve staroslověnských památkách, ale i v řečtině a latině běžného »a« poněkud překvapivý.

V breviáŕi se v úryvcích z Exodu poprvé vyskytuje jméno êrunb v Ex 4,14, tedy $\mathrm{v}$ neparimejní části a $\mathrm{v}$ této podobě se $\mathrm{v}$ chorvatskohlaholské tradici důsledně používá $\mathrm{v}$ textech ze všech biblických knih, včetně žaltáře. Jedinou 
výjimkou je právě v žaltáři měkké přivlastňovací adjektivum od něj odvozené, které má jasně před náslovným »ja« ještě »jik: iêrunb v Ps 113,18; 113,20; 117,3 a 134,19 (dle edice ŠIMIĆ 2014).

V parimejníku i v ostatních nejstarších staroslověnských památkách je toto jméno většinově v podobě aponz či adponz. Při podrobnějším studiu forem doložených v nejstarších staroslověnských památkách však i v nich ojediněle nalézáme zápisy hláskově podobné těm $\mathrm{v}$ chorvatskohlaholských památkách. Tak náslovné »ja« místo »a« nacházíme v Makedonském apoštolu ${ }^{6}$ na čtyřech místech (2x Hb 5,4; Hb 9,4 a označení perikopy na 57b/247) a jméno je tam ve formě ‘pons. Podobný jev, kdy místo většinového náslovného »a« čteme literu »jat'« je i v Sinajském žaltáři (SEVER'JANOV 1922) u jména asur (výše uvedeno i zde), kde v Ps 82,9 nacházíme formu 'scoypz, zatímco v ostatních žaltárích, včetně chorvatskohlaholských je obvyklá forma acoyp. Střídání »jat'« a »a《 v hlaholici a zejména pak při přepisu do cyrilice však bylo poměrně rozšířené, zahrnovalo i slova obecná a důvodem $\mathrm{k}$ němu pak byl zřejmě odlišný fonologický systém nářečí, pro které byla původně hlaholice sestrojena (STANKOVSKA 2019). Z těchto skutečností pak můžeme soudit, že náslovné »ja « u jména êrunb mělo spíše původ ve staroslověnském rukopise, z něhož bylo převzato do chorvatskohlaholské tradice, než prrímo v této tradici samotné.

Jiná je otázka »u« místo obvyklého »o《. I zde sice nalezneme podobný jev v Sinajském žaltáři, kde je v Ps 113,20 doloženo odvozené adjektivum apoyнoвz místo Ароновz v ostatních žaltáŕích. Avšak vzhledem k tomu, že v chorvatskohlaholské tradici existují záměny »o« samohláskou »u«, např. apustol za lat. apostolus,${ }^{8}$ je možné, že se podobně vyvinulo »u« ve jménu êrunb.

\subsubsection{Některá jména jsou oproti cizojazyčným předlohám do} breviárniho textu dodaná, jiná vynechaná nebo výrazně zkomolená, prípadně odvozená z latinské podoby

Ex 2,1: v tomto neparimejním verši, který je dochován pouze v Breviáři Vita z Omišlje (VO) je dodáno jméno Mojžíšovy matky, kterou jmenuje $h a-$

6 Podle údajů v kartotéce k Slovniku jazyka staroslověnského, která je majetkem Slovanského ústavu Akademie České republiky v Praze.

7 Podle edice Makedonského (Strumického) apoštola (BLAHOVA; HAUPTOVA 1990).

8 Reflexe latinského »o« na chorvatskohlaholské »u« je doložena i v dalších výpůjčkách, v některých př́padech i jako variantní $\mathrm{k}$ » « napr.: baron/barun $\mathrm{z}$ lat. baro, bumbak $\mathrm{z}$ lat. bombax, burdel z lat. bordellum, ojediněle je doloženo i »o« jako reflexe latinského »u«: kapitul/ kapitol z lat. capitulum (MIHALJEVIĆ 2014: 386-388). 
velb, i když je její jméno Jochebet. Žádná z částí biblického textu, kde by se jméno Mojžíšovy matky vyskytovalo, však v textu Exodu obsaženém v chorvatskohlaholských knihách, není. Stejně tak není ani v parimejních částech textu. Ve verši Ex 6,20 se v edici překladu celé knihy Exodus vyskytuje ve variantách иаховеть, ишХавє,, ь, иахаветь (VILKUL 2015).

Ex 2,18: v tomto verši, který je opět doložen pouze v Breviáři Vita z Omišlje, je vynecháno jméno otce madiamských dívek Ragoula:

prišbdšem'že imb abie kb o(tb)cu svoemu reče imb čto est'se. da usko-

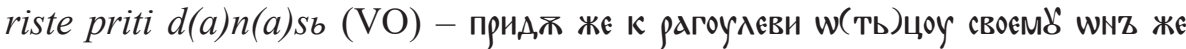
рече почто Бко оускористе прити А(ь)несъ Grig - Quae cum revertissent ad Ra-

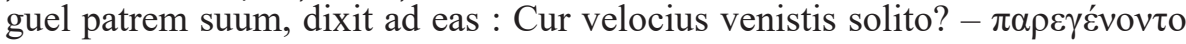

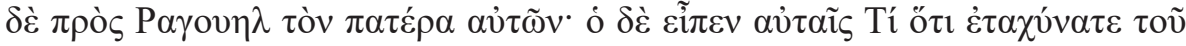

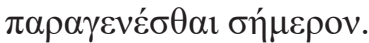

Z citátu celého verše je patrné, že $v$ breviár̆i je několik nápadných odchylek od parimejního znění i od neslovanských textů. Je možné že je to, stejně jako i elipsa jména otce madiamských dívek, pouze další z mnoha koruptel, které nacházíme v Breviáři Víta z Omišlje. To však bude třeba posoudit v rámci jiné práce.

Ex 2,22: hláskoslovně jsou jedna z nejzajímavějších (kromě jména Mojžísova bratra Arona, o kterém bylo pojednáno v 2.1.2. c) jména Mojžíšových synů Gersama a Eliezera, zejména prvního z nich:

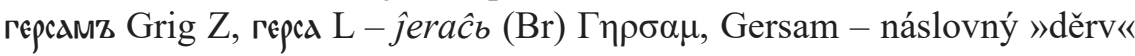
v chorvatskohlaholském textu odpovídá obvyklému préepisu $\Gamma^{r}$ (viz 2.1.1), obtížněji vysvětlitelná je druhá část jména. Snad by mohla vzniknout jakousi přsmyčkou z podoby jména repeca, anebo chybnou interpolací nejasného místa $\mathrm{v}$ předloze.

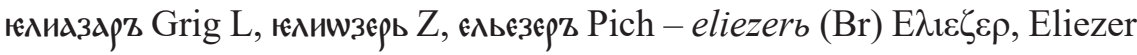
- podoba jména druhého syna se $\mathrm{v}$ breviáŕi velmi blíží originální řecké i latinské a naopak se vzdaluje od podoby ve většině parimejníků, i když v jednom rukopise parimejníku se vyskytuje blízká forma exьњ3єpz. Podobně blízkou formu, ovšem v relativně pozdním dokladu z Ostrožské bible nacházíme i v edici překladu celé knihy єлнєзєер (VILKUL 2015). V tomto prŕpadě tedy nelze jednoznačně rozhodnout, zda jméno ve VO je přejaté z parimejního textu, anebo utvořené podle neslovanské předlohy.

Ex 3,1: v biblickém textu se ve všech breviárích jednotně objevuje jméno posvátné hory Oreb ve formě jasně vycházející z latinského Horeb, zatímco

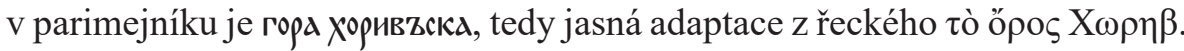
S patřičně zachovanými stopami fonetické platnosti jednotlivých hlásek $(\eta \beta)$ 
$\mathrm{v}$ řečtině. Avšak i u tohoto jména $\mathrm{v}$ breviáři nacházíme jasné stopy hláskové podoby převzaté z řečtiny. Po skončení textu druhé kapitoly je totiž v Breviář́ Vita $z$ Omišlje v doplněném nebiblickém textu: ${ }^{9} B(o g)$ b že pom(i)lovavb e évi se moisěju pasuću na gorě horiv'cě (VO). V tomto nebiblickém dodatku se pojmenování hory velmi podobá formě, která je v parimejníku.

Ex 3,8: většinu názvi̊ měst Země zaslíbené: hananěe $i$ atěe/var. etera $\mathrm{LJ} /$ - $i$ amorěe $\cdot i$ perezěe $\cdot i$ evěe $\cdot i$ buzěi $i$ erěe $(\mathrm{Br})$, která $\mathrm{v}$ parimejníku vyjmenovaná vůbec nejsou, můžeme snadno vztáhnout $\mathrm{k}$ formám latinským, i když se tyto nijak výrazně neliší od řeckých: ad loca Chananei et Hethaei et

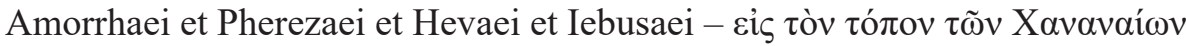

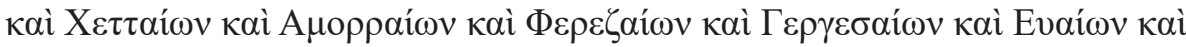

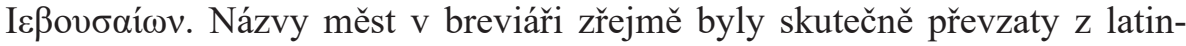
ských forem (v překladu celé knihy Exodus jsou vždy adjektiva: Ханамeиске, Хеттениско, аморенско, ферезеиско, єоуньско, гергесенско, єоусеиско - dle VILKUL 2015), i když jsou v některých př́padech výrazně přeformovaná. Potvrzují se tu však některé zvyklosti při přejímaní, např. »f« je přeisováno jako »p« (perezěe) a náslovné »ii je vynecháváno (buzěi).

\section{ZÁVĚR}

Z parimejního textu knihy Exodus, který se vyskytuje v chorvatskohlaholských breviářích a misálech, bylo vyexcerpováno celkem 163 proprií, z nichž mnohá se několikrát opakují. Eliminací opakování jsme získali 42 proprí́.

Ze srovnání s jejich podobou v parimejním textu jasně vyplynulo, že většina z nich je v chorvatskohlaholské tradici ve stejné formě, která mnohdy vykazuje znaky př́mého přejetí z řečtiny, jako v parimejníku a to i v př́ípadě, že se parimejní podoba jména liší od řecké a latinské. Takových jmen je zhruba polovička, tedy 22, dalších 10 jmen vychází opět z formy parimejní, jsou v nich však pravidelné změny: ztráta náslovného »i« (êkovb, sahar', liopolb, otor') nebo změna »f « na »p« (neptalim', paraon', pitonb, sep'pora, puva, pilistim') či obojí (osip '). Jméno Mojžíšova bratra Arona se v celé chorvatskohlaholské tradici vyskytuje ve formě êrunb, ale okrajový výskyt podobných hláskových kombinací v nejstarších staroslověnských rukopisech nasvědčuje tomu, že v této poněkud zvláštní formě bylo jméno opsáno z některého ze staroslověnských rukopisů a není tedy výsledkem úprav v chorvatském prostředí.

9 Celý text je vydán v STANKOVSKA 2019. 
Zbytek analyzovaných jmen jsou většinou jména měst v zemi zaslíbené, která jsou hláskově bud' stejná jako latinská i řecká, anebo neprůhledná, přesto však potvrzují tendence pro přjímání cizích jmen do chorvatskohlaholského textu - ztrátu náslovného »i« a změnu »f« na »p«. K nejasným patř́i i forma jména prvního Mojžíšova syna jeraĉb (v parimejníku obvykle гepcamz, герсa), na druhou stranu posvátná hora Oreb je sice v biblickém textu (Ex 3,1) v podobě odpovídající latinské formě, nicméně v nebiblickém textu za druhou kapitolou je ve formě stejné jako v parimejníku Horiv'.

\section{ZKRATKY RUKOPISŮ}

DR - Dragučský breviár̆, 1407, pergamen, Záhřeb, Arhiv HAZU, sign. IIIb25.

Grig - Grigorovičův parimejnik, 12.-13. stol., pergamen, Moskva, Ruská státní knihovna, sign. M. 1685.

Hrv - Hrvojův misál, 1404, pergamen, Istambul, knihovna Topkapi Saraj.

ILL - Vatikánský 10. breviár̆, 1485, pergamen, Rím, Biblioteca Apostolica Vaticana, sign. Borg. Illir. 10.

Ill4 - Misál Illirico 4, pol. 14. stol., pergamen, Ř́m, Biblioteca Apostolica Vaticana, sign. Borg. Illir. 4.

L - Lobkovský parimejník, 1294-1320, pergamen, Moskva, Státní historické muzeum, sign. Chlud 142.

LJ - 2. lublaňský breviář, 15. stol., pergamen, Lublaň, Narodna in univerzitetna knjižnica, sign. Ms 163.

Nk - Misál knížete Novaka, 1368, pergamen, Vídeň, Österreichische Nationalbibliothek, sign. Cod. slav. 8.

Ro - Ročský misál, 1421, pergamen, Vídeň, Österreichische Nationalbibliothek, sign. Cod. slav. 4.

VAT - Vatikánský breviár, pol. 14. stol., pergamen, Řím, Biblioteca Apostolica Vaticana, sign. Borg. Illir. 5.

VO - Breviář Vita z Omišlje, 1396, pergamen, Vídeň, Österreichische Nationalbibliothek, sign. Cod. slav. 3.

Z - Zacharijưv parimejník, 1271, pergamen, Petrohrad, Rusná národní knihovna, sign. $Q p$ I.13.

\section{LITERATURA}

BAKMAZ, I. 2010. Biblijska čitanja u hrvatskoglagoljskim misalima. Slovo 60: 73-100.

BLAHOVA, E.; Z. HAUPTOVA (ed.). 1990. Strumički (Makedonski) apostol - kirilski spomenik od XIII vek. Skopje: MANU. 
DIELS, P. 1932. Altkirchenslavische Grammatik mit einer Auswahl von Texten und einem Wörterbuch. Heidelberg.

FILIPOVIĆ, R. 1986. Teorija jezika u kontaktu. Zagreb: JAZU.

FISCHER, B. (ur.) 1983. Biblia Sacra iuxta vulgatam versionem. Stuttgart: Deutsche Bibelgesellschaft.

MIHALJEVIĆ, M. (ur.) 2014. Hrvatski crkvenoslavenski jezik. Zagreb: Hrvatska sveučilišna naklada - Staroslavenski institut.

MIHALJEVIĆ, M. 2017. Tkonski fragmenti brevijara iz 13. stoljeća (v tisku).

MIKLAS, H. et alii 2012. Psalterium Demetrii Sinaitici (monasterii sanctae Catharinae codex slav. 3/N) adiectis foliis medicinalibus. Wien: Verlag Holzhausen.

PANTELIĆ, M.; A. NAZOR. 1977. II. Novljanski brevijar. Hrvatskoglagoljski rukopis iz 1495. godine. Župni arhiv Novi Vinodolski. Fototipsko izdanje. Zagreb - Graz: Staroslavenski institut Svetozar Ritig - Turistkomerc - Akademische Druck- u. Verlagsanstalt

PIČCHADZE, A. A. 1998. Kniga »Ishod «v drevneslavjanskom parimejnike. Moskva.

RAHLFS, A. 1979. Septuaginta. Id est Vetus Testamentum graece iuxta LXX interpretes. Stuttgart: Deutsche Bibelgesellschaft.

RIBAROVA, Z.; Z. HAUPTOVA. 1998. Grigorovičev parimejnik I. Tekst so kritički aparat. Skopje: MANU.

SEVER'JANOV, S. 1922. Sinajskaja psaltyr'. Glagoličeskij pamjatnik XI veka. Petrograd: Rossijskaja akademija nauk.

SJS 1996-1997 = Slovník jazyka staroslověnského I.-IV. J. Kurz; Z. Hauptová (ed.). Praha: Academia, Euroslavica.

STANKOVSKA, P. 2018. Knjiga Eksodus v srednjeveških hrvaškoglagolskih brevirjih in misalih. Slavistična revija : časopis za jezikoslovje in literarne vede 66/2: 159-169.

STANKOVSKA, P. 2019. Kniga Ishod v breviarii Vida Omišljanina - tekstologičeskie i perevodčeskie osobennosti. V. S. Efimova, (ur.). Paleoslavistika - 2 (Slavjanskoe i balkanskoe jazykoznanie). Moskva: Institut slavjanovedenija RAN: 371-396.

STANKOVSKA, P. 2019. Zápis staroslověnské spojky a částice ašte/aćelešte - ěšte/ěće - eče v nejstarších staroslověnských památkách. Radić, J.; V. Savić, (ur.). Nasleđe $i$ stvaranje, Sveti Ćirilo - Sveti Sava, 869 - 1219 - 2019. Beograd: Institut za srpski jezik SANU: 199-212.

ŠIMIĆ, M. 2014. Akademijin brevijar HAZU IIIc12. Zagreb: Staroslavenski institut.

ŠTEFANIĆ, Vj. (ur.) 1973. Missale Hervoiae ducis spalatensis croato-glagoliticum. Ljubljana - Graz - Zagreb: Staroslavenski institut - Mladinska knjiga - Akademische Druck- u. Verlagsanstalt.

VILKUL, T. L. 2015. Kniga Ishod: Drevněslavjanskij polnyj (četij) tekst po spiskam XIV-XVI vekov. Moskva: Kvadriga. 
S ažetak

\section{Petra STANKOVSKA}

\section{VLASTITA IMENA U PARIMEJNOM TEKSTU KNJIGE IZLASKA U HRVATSKOGLAGOLJSKIM BREVIJARIMA I MISALIMA}

Cilj je ovoga priloga analizirati oblik vlastitih imena koja se pojavljuju u hrvatskoglagoljskim brevijarima i misalima u dijelovima biblijske Knjige Izlaska i paralelno u staroslavenskim parimejnicima. To su retci: Iz 1,1-20; 2,5-22; 3,1-8; 12,1-11; 13,20-22; 14,1-31; 14,24-29; 15,1; $15,1-19 ; 15,22-27 ; 15,27-16,1 ; 18,4$ i 24,12-18. Na nekoliko mjesta u analizu smo uključili više imena iz neparimejnih dijelova. Ukupno su pronađena 163 vlastita imena, od kojih se većina u tekstu pojavljuje više puta. Zanemarimo li ponavljanja, dobit ćemo 42 imena razdijeljena u tri grupe: (1) u parimejniku i hrvatskoglagoljskim brevijarima i misalima u istom su obliku; (2) u hrvatskoglagoljskoj su tradiciji glasovno drugačija nego u parimejnom tekstu; (3) u hrvatskoglagoljskoj tradiciji dodana su ili ispuštena imena, ili su pod utjecajem latinske verzije. U prvoj skupini je 21 ime, u drugoj je 11 imena, od kojih 10 ima redovite glasovne promjene u usporedbi s parimejnom oblikom - ispadanje početnog »i« (tip: u'tkoвz - êkovb), zamjena »f« $\mathrm{s} » \mathrm{p} \ll$. $(\phi у в а-p u v a)$ - i ime êrunь (parimejno aponz) koje je u ovom obliku vjerojatno preuzeto još iz staroslavenskoga rukopisa. U trećoj je skupini jedno ime dodano, jedno ispušteno, sljedeće ime jednog od Mojsijevih sinova (eliezerb) odgovara rijetkoj formi u parimejnicima, a ime drugoga sina ima poseban, teško razumljiv oblik jeraćb. Ime svete gore Oreb je u brevijarima u biblijskom tekstu (Iz 3,1) jasno preuzeto iz latinskog oblika, ali u dodanom nebiblijskom tekstu u Brevijaru Vida Omišljanina nalazimo ga u parimejnom obliku. Teško je odrediti odakle su preuzeta imena gradova u Obećanoj zemlji, ali najvjerojatnije iz latinske verzije. I ovdje je potvrđena ista namjera kako i kod imena druge skupine: početno »i« se gubi, a »f« se mjenja $\mathrm{u} » \mathrm{p} \ll$.

Ključne riječi: Knjiga Izlaska, staroslavenski, hrvatski crkvenoslavenski, prijevod, vlastita imena

Petra STANKOVSKA

Filozofski fakultet Sveučilišta u Ljubljani

Ljubljana (Slovenija)

petra.stankovska@ff.uni-lj.si 
